\title{
HAK PATEN MINUMAN DARI KULIT MANGGIS PADA PT ZENA SENTOSA NIRMALA
}

\author{
Sulistyawati \\ 155100094 \\ Fakultas Komputer, 448757167 \\ sulistyawati/.student@umitra.ac.id
}

\begin{abstract}
PT. Zena Nirmala Sentosa didirikan pada tahun 1992 di Jakarta. PT ini bergerak di bidang industri makanan dan suplemen yang memproduksi produk-produk kesehatan berbahan alami. Salah satu produknya adalah ekstrak kulit manggis Garcia. Gracia ini merupakan ekstrak kulit manggis berkhasiat tinggi. Buah Manggis dikenal sangat kaya dengan zat ajaib yang disebut xanthone, yang dapat mencegah berbagai penyakit. Minuman kesehatan dari kulit buah manggis ini sudah dipatenkan Ditjen Hak Kekayaan Intelektual (HaKI),
\end{abstract}

Kata Kunci : hak paten garcia, hak paten kulit manggis 


\section{A. INTRODUCTION}

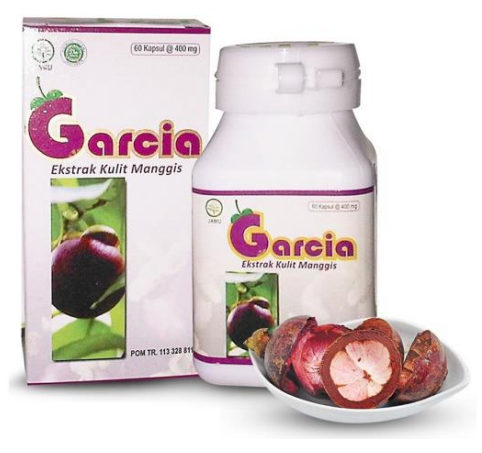

PT. Zena Nirmala Sentosa didirikan pada tahun 1992 di Jakarta. PT ini bergerak di bidang industri makanan dan suplemen yang memproduksi produk-produk kesehatan berbahan alami. Salah satu produknya adalah ekstrak kulit manggis Garcia.

Garcia manggis merupakan Ekstrak Kulit Manggis berkhasiat tinggi. Buah Manggis dikenal sangat kaya dengan zat ajaib yang disebut xanthone,di dalam tubuh manusia. di kalangan medis dan farmasi, manggis dijuluki queen of fruits alias ratu segala buah. Selain itu, kulit manggis juga banyak mengadung katekin, potasium, kalsium, fosfor, besi, vitamin $\mathrm{B} 1$, vitamin $\mathrm{B} 2$, dan vitamin B6. Semua zat ini amat dibutuhkan tubuh. Orac adalah singkatan dari oxygen radical absorbance capasity, yakni kemampuan antioksidan menetralkan radikal bebas penyebab penyakit. Karena itu, xanthone mampu menjadi pelindung sel pada proses oksidasi, penuaan, atau perusakan oleh radikal bebas. Sifat antioksidannya melebihi vitamin $\mathrm{E}$ dan vitamin $\mathrm{C}$.

Xanthone ditemukan ilmuwan Jerman tahun 1855. Ia dikenal sebagai antioksidan tingkat tinggi dan bahan aktif yang stabil dalam keadaan panas atau dingin, termasuk di dalam tubuh manusia. Kulit manggis mengandung antioksidan 17.000-20.000 orac per 100 ounce. Padahal, bahan lain berkadar antioksidan tinggi, seperti wortel dan jeruk, hanya 300 dan 2.400 proses penelitian minuman yang dibuat dari bahan baku kulit buah manggis itu sudah dimulai sejak 2005 dengan melibatkan setidaknya 40 orang tenaga ahli dari BPTP Sumbar. pengajuan untuk hak paten tersebut sudah dilakukan sejak 2006, setelah menunggu penantian panjang dari Kemenkum HAM akhirnya permintaan tersebut dikabulkan dengan nomor ID P0028639 B, 30 Juni 2011.

Temuan Balai Pengkajian Teknologi Pertanian (BPTP) Sumatera Barat terkait minuman kesehatan dari kulit buah manggis sudah dipatenkan Ditjen Hak Kekayaan Intelektual (HaKI) Kementerian Hukum dan Hak Azazi Manusia pada Juni 2011.

\section{B. CONCLUSION}

Garcia merupakan ekstra kulit manggis yang mempunyai khasiat untuk menyembuhkan penyakit diabetes dan dapat mencegah berbagai macam penyakit. Gracia sudah mempunyi hak paten pada tahun 2011.

\section{ACKNOWLEDGEMENT University Of Indonesia University Of Mitra Indonesia Telkom University University Of Mellbourne Saitama University}




\section{REFERENCE (Based ISO 690)}

[1]

\begin{abstract}
A. S. Putra And O. M. Febriani, "Knowledge Management Online Application In Pdam Lampung Province," In Prosiding International Conference On Information Technology And Business (Icitb), 2018, Pp. 181-187.
\end{abstract}

[2] A. S. Putra, O. M. Febriani, And B. Bachry, "Implementasi Genetic Fuzzy System Untuk Mengidentifikasi Hasil Curian Kendaraan Bermotor Di Polda Lampung," J. Sist. Inf. Dan Manaj. Basis Data, Vol. 1, No. 1, Pp. 21-30, 2018.

[3] O. M. Febriani And A. S. Putra, "Sistem Informasi Monitoring Inventori Barang Pada Balai Riset Standardisasi Industri Bandar Lampung," J. Inform., Vol. 13, No. 1, Pp. 90-98, 2014.

[4] Putra, Arie Setya. "2018 Artikel Struktur Data, Audit Dan Jaringan Komputer." (2018).

[5] Putra, A. S. (2018, July 17). Paperplain Fundamental Create Application With Borland Delphi 7.0 University Of Mitra Indonesia. Retrieved From Osf.Io/Pbrn9.

\section{E. REFERENCE (Based APA)}

Putra, A. S., Aryanti, D. R., \& Hartati, I. (2018, November). Metode SAW (Simple Additive Weighting) sebagai Sistem Pendukung Keputusan Guru Berprestasi (Studi Kasus: SMK Global Surya). In Prosiding Seminar Nasional Darmajaya (Vol. 1, No. 1, pp. 85-97).

Sari, D. P., Febriani, O. M., \& Putra, A. S. (2018, November). Perancangan Sistem Informasi SDM Berprestasi pada SD Global Surya. In Prosiding Seminar Nasional Darmajaya (Vol. 1, No. 1, pp. 289-294).

Putra, A. S. (2018). Paperplain: Execution Fundamental Create Application With Borland Delphi 7.0 University Of Mitra Indonesia.

Putra, A. S., Sukri, H., \& Zuhri, K. Sistem Monitoring Realtime Jaringan Irigasi Desa (JIDES) Dengan Konsep Jaringan Sensor Nirkabel. IJEIS (Indonesian Journal of Electronics and Instrumentation Systems), 8(2), 221232.

Darmawan, A., Yuliawati, D., Marcella, O., \& Firmandala, R. (2016). Sistem Absensi dan Pelaporan Berbasis Fingerprint dan SMS Gateway. EXPLORE, 7(1). 
Febriani, O. M., Wahyuni, T., \& Yusuf, S. (2017). DESIGN OF WEBSITE-BASED INFORMATION SYSTEM FOR EDOCUMENT

ADMINISTRASI IN THE
COMMUNITY SERVICE UNIT (A Case Study at Rajabasa District). INTERNATIONAL JOURNAL OF COMPUTERS \& TECHNOLOGY, 16(7), 7010-7020.

Febriani, O. M., \& Wahyuni, T. (2017, October). PERANCANGAN SISTEM E-DOCUMENT ADMINISTRASI LOGBOOK PENELITIAN PADA UNIT LAYANAN DI BANDAR LAMPUNG. In Prosiding Seminar Nasional Darmajaya (Vol. 1, No. 1, pp. 187-194).

Febriani, O. M., \& Permadi, A. B. (2017). Implementasi Sistem Aplikasi Data Bimbingan dan Pelanggaran Siswa pada Sekolah Menengah Atas di Lampung Tengah dengan Metode Analisis dan Desain Sistem Terdistribusi (SSAD). EXPERT, 7(1).

Febriani, O. M., \& Ambarwati, L. (2015). PERANCANGAN APLIKASI PENGOLAHAN DATA PENJUALAN UKM KELANTING KHAS TELO DESA SIDOHARJO KECAMATAN JATI AGUNG KABUPATEN LAMPUNG SELATAN. Jurnal Teknologi Informasi dan Bisnis Pengabdian Masyarakat Darmajaya, 1(1), 77-95.

Febriani, O. M. (2015). Rancang Bangun Aplikasi Ecommercemenggunakan Freewebstore pada UKM Kelanting di Desa Sidoharjo Lampung Selatan. Prosiding Sembistek 2014, 1(02), 446-458. 